\title{
COMPARISON OF THE PROPERTIES OF PORTLAND CEMENT AND PORTLAND-LIMESTONE CEMENT
}

\author{
Alex Lyatonga Mrema \\ Department of Structural and Construction Engineering, College of \\ Engineering and Technology, University of Dar es Salaam, P. O. Box \\ 35131,Dar es Salaam, Tanzania. Tel. +255 754 285715, Email: \\ mrema@ce.udsm.ac.tz
}

\begin{abstract}
A study was made in a cement factory in Dar es Salaam, Tanzania, where Ordinary Portland Cement (CEM I 42.5N) and Portland-limestone cement (PLC) which has the brand name Twiga Cement Extra (CEM II/A-L/32.5R) are produced and conforming to the Tanzania Standard TZS 727 (Part1): 2002, which is equivalent to EN 197 published by the committee for European normalization (CEN). A comparison was made between the two types of cements in terms of physical, chemical and mechanical properties. It was found out that they all complied with the standards, that there was no significant difference in their setting times and that the Portland cement had higher strengths than the PLC. It was also observed that there was a slightly lower water demand for the same consistency when compared to OPC and hence there is an improvement of the cohesiveness of a concrete mix when PLC is used. It was concluded, however, that the two cements are different and that using the two cements interchangeably as is done in Tanzania is wrong because they do not have equivalent strengths and therefore equivalent performance since the PLC is not optimized. Portland-limestone cement (PLC) is known to offer significant energy savings and green house gas (GHG) reduction (up to $10 \%$ GHG savings) over conventional Portland cement while at the same time providing comparable performance if optimized.
\end{abstract}

Keywords: Portland cement, Portland-limestone cement, properties, optimization

\section{INTRODUCTION}

\section{What are Portland-limestone cements?}

Portland-limestone cements are a type of common cement specified by BS EN 1971: 2000 . There are two types containing 6$20 \%$ and $21-35 \%$ limestone fines respectively. Portland-limestone cements containing up to $20 \%$ limestone fines were previously specified in the UK by BS 7583: 1996. The cement designations for factory made Portland-limestone cements are CEM II /A-L (or A-LL) and CEM II /B-L (or B-LL) where:

- CEM II /A-L (or A-LL) may contain $6-20 \%$ limestone.

- CEM II /B-L (or B-LL) may contain 21-35\% limestone.
The suffix - LL, rather than $-\mathrm{L}$ signifies a source of high purity limestone with a particularly low content of organic material. The limestone is generally interground (rather than blended) with Portland cement clinker and the cements are available at standard strength class 42.5/52.5 and when air-entrained 32.5R. Portland-limestone cement should not be confused with Portland cement (CEM I) which is permitted to contain up to $5 \%$ of a minor additional constituents (m.a.c.) (Hawkins et al. 2003). The m.a.c. often used is limestone fines with a particle size similar to cement. A CEM I that includes a limestone m.a.c. is indistinguishable in properties from any other CEM I and can be used whenever and wherever CEM I is specified. 
What is the primary benefit of Portlandlimestone cement?

The manufacture of Portland limestonecement leads to reduced levels of $\mathrm{CO}_{2}$ emissions and reduced energy consumption when compared with the production of the same quantity of Portland CEM I, thus contributing towards more sustainable construction (Nisbet, 1996 and Townson, 2009).

What are the effects of Portland-
limestone cement on concrete
properties?

The properties of fresh concrete made with PLC are similar to those of a concrete containing a CEM I cement although the tendency to bleeding is significantly reduced (Albeck et al., 1991). At the same water/cement ratio, concrete made using PLC can have a slightly lower 28 day compressive strength than concrete made using CEM I therefore higher cement contents may be required to achieve the same strength (Hawkins, 1986). Sprung \& Siebel (1991) found that in general concretes made with Portland limestone cements (6 to 20\% limestone) showed increased rates of carbonation as compared with those made with Portland cements. BS 8500:2002 applies the same prescriptive requirements to PLC concrete exposed to XC (carbonation), XD (de-icing salts), XS (sea water) and XF (freeze-thaw) exposure conditions as it does to CEM I concrete. In accordance with BRE Special Digest 1:2005 (SD 1) both CEM II/A-LL and CEM I cements are suitable for use in aggressive ground up to Design Chemical Class DC-2. Hooton (1990), reports that sulphate resistance is not affected by carbonate and is primarily determined by $\mathrm{C}_{3} \mathrm{~A}$ content. It has to be pointed out, however, that literature contained mixed data on carbonation, sulphate exposure, and the development of thaumasite. While questions of carbonation have been answered, the Canadian Standards will not permit PLC to be used in sulphate exposure environments until further tests are carried out (Townson, 2009).

\section{How new is Portland-limestone cement?}

PLC is not new. PLC has been successfully used in Europe for 25 years now. A good example of the application of PLC is the Gotthard tunnel in Switzerland which is $57 \mathrm{~km}$ long and used CEM II A-L cement for the concrete paving. As far back as 1965 Germany was using PLCs. This cement is simply new to few developed countries like Canada and the US. The US allowed 5\% limestone additions in 2004 and more recently in 2007 in AASHTO M85 Standard (Townson, 2009). It is, however, very new to most developing countries like Tanzania.

What is the current state of art of research in PLCs?

Hooton et al (2007) revealed that the performance of concrete produced with PLC was affected by the quality and particle size distribution of the limestone. In producing and testing PLC in Canada, it was found out that intergrinding the clinker and the limestone was the best way to ensure that the proper particle size and distribution (i.e. optimization) was achieved. In Canada all Portlandlimestone cements will be manufactured to produce similar strength concrete to that obtained with Portland cement. Durability tests performed in Canada confirmed some findings noted in a literature survey conducted earlier by the Canadian Standards Association A3000 Technical Committee. PLC is prohibited for use in sulphate environments in Canada as tests are ongoing on this issue although preliminary results look promising (Townson, 2009). 


\section{DETERMINATION OF PROPERTIES OF PORTLAND CEMENT AND PORTLAND- LIMESTONE CEMENT}

The cements compared were Portland cement (CEM I $42.5 \mathrm{~N}$ ) and Portlandlimestone cement (CEM II/A-L/32.5R) and were tested according to the European Standard EN 196 and checked for conformity with Tanzania Standard TZS 727-2002 which is equivalent to EN 197. The tests carried out were physical, mechanical and chemical tests.

\section{Physical tests}

The physical tests carried out were determination of setting times and soundness according to EN 196: Part 3, and fineness according to EN 196: Part 6.

\section{Mechanical tests}

The mechanical tests done were determination of compressive strengths according to EN 196: Part 1. Mortar cubes of size $7.01 \times 7.01 \times 7.01 \mathrm{~cm}$ were used and the test equipment was a compression machine type MFL 300 MPF.

\section{Chemical tests}

The chemical tests done were loss on ignition, insoluble residue, chemical composition of the cement and its raw materials by XRF analysis according to EN 196: Part 2 and determination of the chloride, carbon dioxide and alkali content of the cements according to EN 196: Part 21.

\section{TEST RESULTS}

Table1: Physical properties of the cements tested

\begin{tabular}{|l|l|l|l|}
\hline Physical Test & $\begin{array}{l}\text { Portland cement } \\
\text { (CEM I 42.5N) }\end{array}$ & $\begin{array}{l}\text { Portland-limestone } \\
\text { cement (CEM II/A- } \\
\text { L/32.5R) }\end{array}$ & $\begin{array}{l}\text { Requirements according } \\
\text { to EN 197-1 }\end{array}$ \\
\hline $\begin{array}{l}\text { Standard } \\
\text { Consistence test } \\
(\%)\end{array}$ & 26 & 25.5 & None \\
\hline $\begin{array}{l}\text { Initial setting time } \\
(\mathrm{min})\end{array}$ & 179 & 169 & $\geq 60, \geq 75$ respectively \\
\hline Soundness $(\mathrm{mm})$ & 1.5 & 1.0 & $\leq 10$ \\
\hline Fineness $\left(\mathrm{cm}^{2} / \mathrm{g}\right)$ & 3669 & 3776 & $\geq 2250$ \\
\hline
\end{tabular}

Both cements passed the physical properties tests.

Table 2: Mechanical Properties of the cements tested

\begin{tabular}{|l|l|l|l|}
\hline Cement Type & $\begin{array}{l}\text { Early strength } \\
\text { (2 days) }\end{array}$ & $\begin{array}{l}\text { Standard } \\
\text { strength } \\
\text { (28 days) }\end{array}$ & $\begin{array}{l}\text { Requirements } \\
\text { according to EN } \\
197-1\end{array}$ \\
\hline Portland cement (CEM I 42.5N) & $16.95 \mathrm{MPa}$ & $\begin{array}{l}>10 \mathrm{MPa} \text { at 2days } \\
\text { and between } 42.5 \\
\text { and } 62.5 \mathrm{MPa} \text { at } \\
28 \text { days }\end{array}$ \\
\hline $\begin{array}{l}\text { Portland-limestone cement } \\
\text { (CEM II/A-L/32.5R }\end{array}$ & $13.14 \mathrm{MPa}$ & $41.98 \mathrm{MPa}$ & $\begin{array}{l}>10 \mathrm{MPa} \text { at 2days } \\
\text { and between } 32.5 \\
\text { and 52.5 MPa at } \\
28 \text { days }\end{array}$ \\
\hline
\end{tabular}

Both cements passed the mechanical properties tests. 
Table 3: Chemical test results for the cements tested

\begin{tabular}{|l|l|l|l|}
\hline Test & $\begin{array}{l}\text { Portland cement } \\
\text { (CEM I 42.5N) }\end{array}$ & $\begin{array}{l}\text { Portland-limestone cement } \\
\text { (CEM II/A-L/32.5R) }\end{array}$ & $\begin{array}{l}\text { Requirements } \\
\text { according to EN 197-1 }\end{array}$ \\
\hline $\begin{array}{l}\text { Loss on } \\
\text { Ignition (\%) }\end{array}$ & 4.2 & 5.5 & $\leq 5.0$ \\
\hline $\begin{array}{l}\text { Insoluble } \\
\text { Residue (\%) }\end{array}$ & 1.5 & 2.3 & $\leq 5.0$ \\
\hline $\mathrm{CaO}(\%)$ & 66.6 & 66.3 & None \\
\hline $\mathrm{SiO}_{2}(\%)$ & 21.5 & 21.1 & None \\
\hline $\mathrm{CaO}_{\mathrm{SiO}}$ & 3.1 & 3.1 & $\geq 2.0$ \\
\hline $\mathrm{Al}_{2} \mathrm{O}_{3}(\%)$ & 4.6 & 4.9 & None \\
\hline $\mathrm{Fe}_{2} \mathrm{O}_{3}(\%)$ & 2.8 & 2.7 & None \\
\hline $\mathrm{MgO}(\%)$ & 1.2 & 1.0 & $\leq 5.0$ \\
\hline $\mathrm{SO}_{3}(\%)$ & 2.7 & 2.6 & $\leq 3.5$ \\
\hline & & &
\end{tabular}

Both cements passed the chemical tests. composition of the clinkers are computed and tabulated on Table 4.

From the oxide composition of the cements, the potential compound

Table 4: Average Potential Compound Composition

\begin{tabular}{|l|l|l|l|}
\hline Compound & $\begin{array}{l}\text { Portland cement } \\
\text { (CEM I 42.5N) }\end{array}$ & $\begin{array}{l}\text { Portland-limestone cement } \\
\text { (CEM II/A-L/32.5R) }\end{array}$ & $\begin{array}{l}\text { Requirements according } \\
\text { to EN 197-1* }\end{array}$ \\
\hline $\mathrm{C}_{3} \mathrm{~S}^{*}$ & 52.9 & 53.1 & \\
\hline $\mathrm{C}_{2} \mathrm{~S}^{*}$ & 21.8 & 20.5 & \\
\hline $\mathrm{C}_{3} \mathrm{~A}$ & 7.5 & 8.4 & \\
\hline $\mathrm{C}_{4} \mathrm{AF}$ & 8.5 & 8.2 & \\
\hline $\mathrm{LSF}$ & 95.8 & 96.6 & \\
\hline $\mathrm{SIM}$ & 2.9 & 2.8 & \\
\hline $\mathrm{ALM}$ & 1.6 & 1.8 & \\
\hline
\end{tabular}

LSF = lime Saturation Factor, SIM = Silica Modular Ratio, ALM = Aluminum oxide to iron oxide ratio

* The sum of the weights of $\mathrm{C}_{3} \mathrm{~S}$ and $\mathrm{C}_{2} \mathrm{~S}$ must be at least two thirds of the weight of the clinker for a

Portland cement

\section{CONTROL CHARTS}

It was of interest to check what the variations were during the production process by taking further samples taken at different weeks during the production process and doing all the tests mentioned in section 2 above. Some of the results are plotted on Figure. 1 to Figure. 4. 


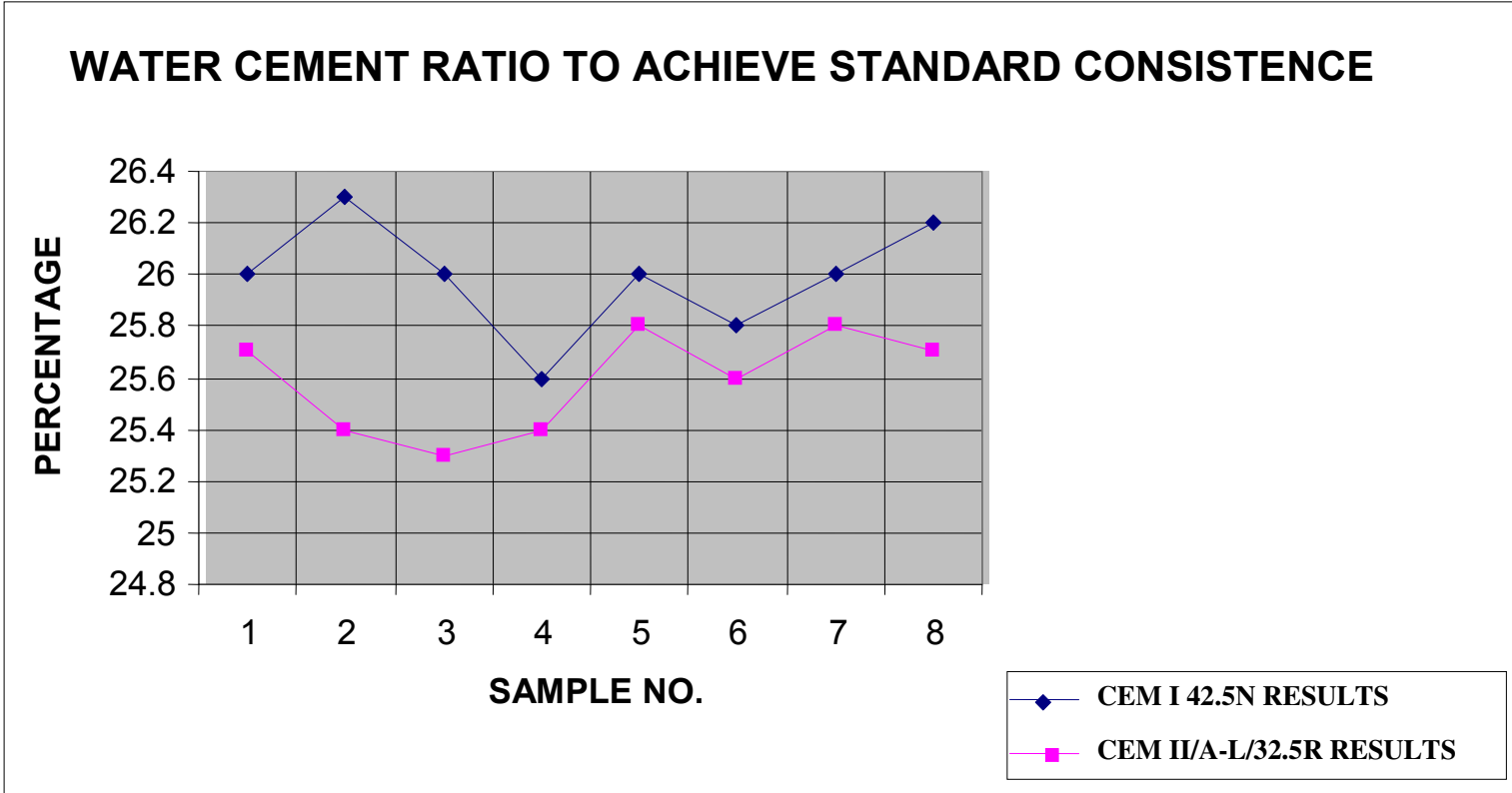

Figure 1: Water cement ratio to achieve standard consistence

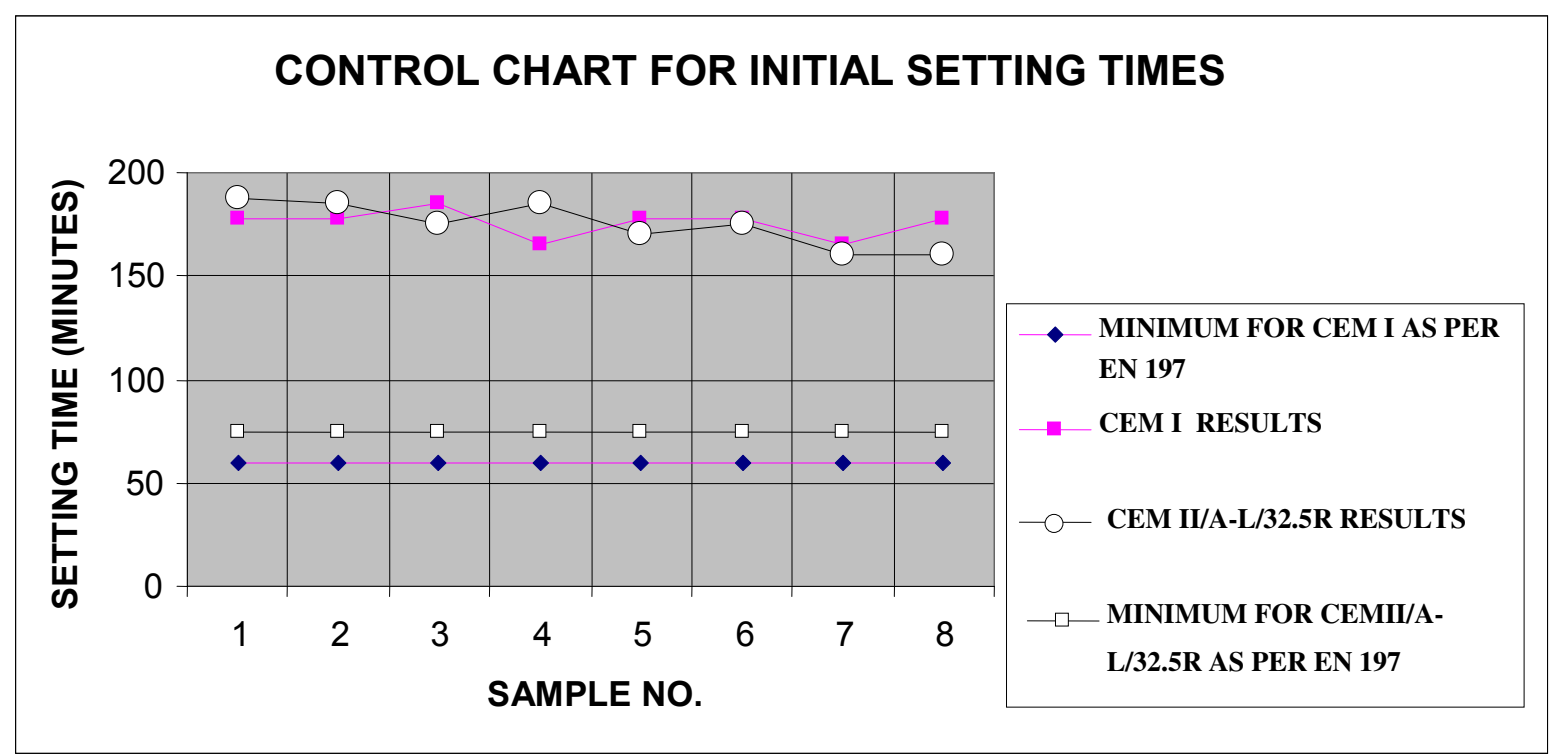

Figure 2: Control Chart for Initial Setting times 


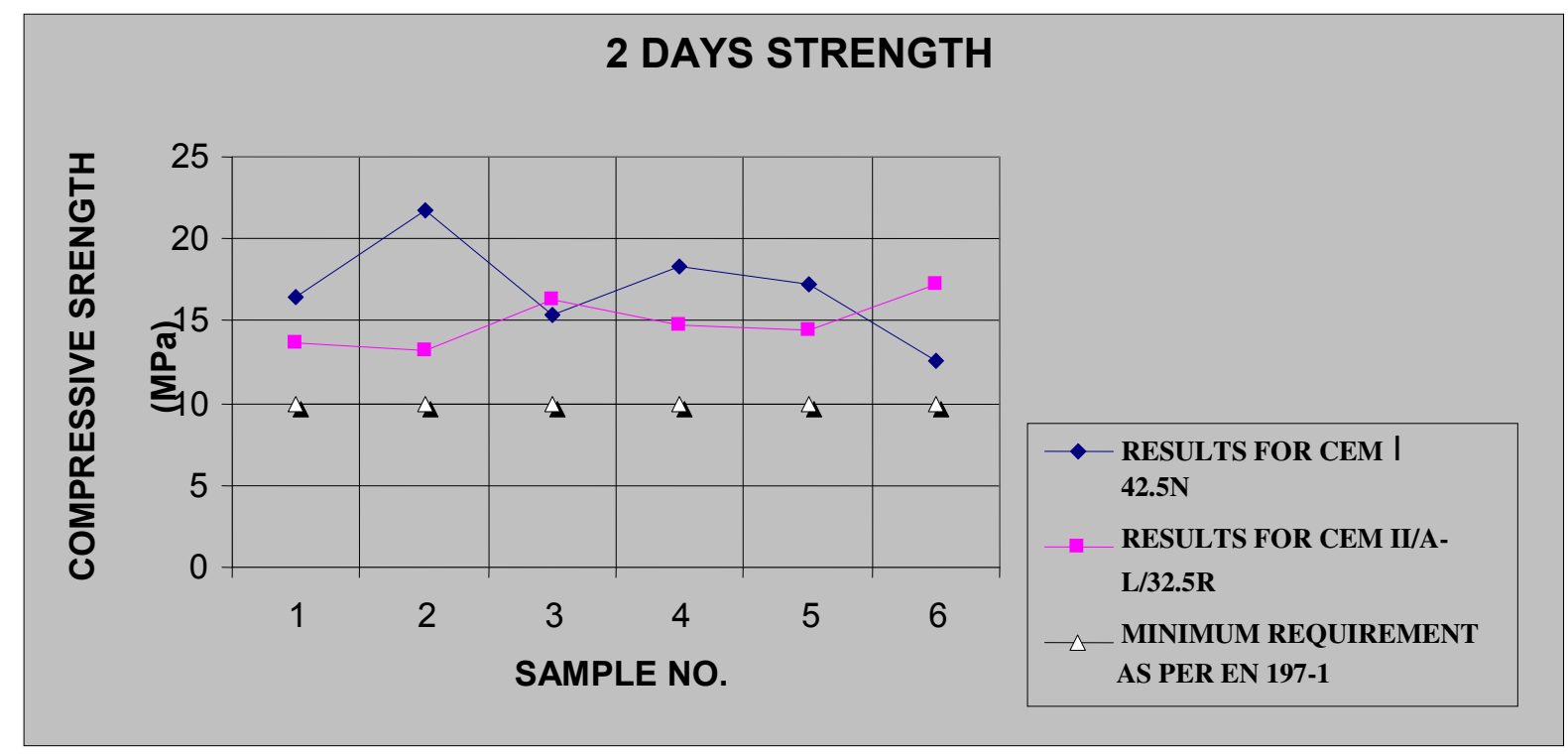

Figure 3: Control chart for 2 days strength

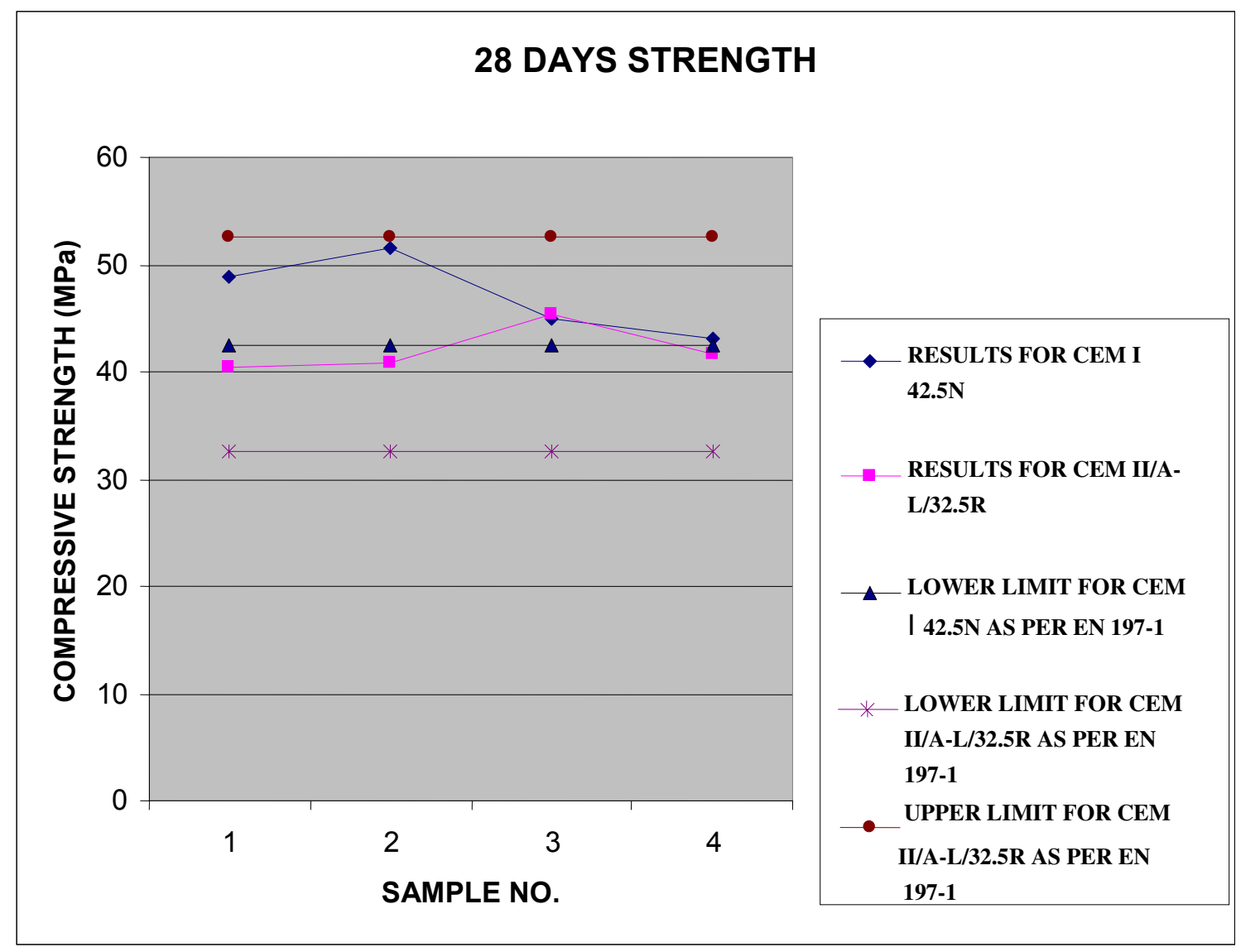

Figure 4: Control chart for 28 days strength 


\section{DISCUSSION OF RESULTS}

The two cements investigated i.e. the Portland cement (CEM I $42.5 \mathrm{~N}$ ) and the Portland-limestone cement (CEM II/AL/32.5R) passed the physical, mechanical and chemical properties as required by the Tanzania Standard: TZS 727 (Part 1):2002 which is equivalent to the European Standard EN 197-1:2000.

The tests have shown that to achieve the same consistency PLC requires less water than Portland cement (Figure 1) which confirms earlier observations by other people that the tendency to bleeding is significantly reduced in concrete made of PLC.

From the tests conducted there was no significant difference in the initial setting times for both cements (Figure 2).

From the control charts for 2 days strength (Figure 3) and the 28 days strength (Figure 4) it shows that the Portland cement has higher strengths than PLC at both ages and therefore the use of both cements interchangeably as the case is in Tanzania is uneconomical. It has been noted in the literature review that performance of concrete produced with PLC was affected by the quality and particle size distribution of the limestone and that if the proper particle size and distribution is not achieved in PLC, a process called 'optimization', then the PLC will not produce equivalent results to a comparable Portland cement.

The use of the PLC and Portland cement (discussed here) interchangeably as the case is in Tanzania assumes that the two cements have equivalent strengths and therefore equivalent durability and performance which has been shown here not to be the case.

\section{CONCLUSIONS}

Portland-limestone cement (PLC) is known to offer significant energy savings and green house gas (GHG) reduction (up to $10 \%$ GHG savings) over conventional Portland cement while at the same time providing comparable performance if optimized.

While the use of PLC has been known in Europe for 25 years now, it is very new in developing countries and even in some developed ones. For example the National Building Code of Canada (NBCC) will reference (allow the use of) PLC in 2010 (Townson, 2009).

It has been observed that while we use PLC in developing countries, (Tanzania in particular), the characteristics of such cements remain largely unknown to builders and even to some practicing engineers because of lack of technical information on such cements. Portlandlimestone cements and Portland cements have very often been used interchangeably even in situations where the PLCs had not been optimized. It is time to disseminate the knowledge on PLCs and the other similar cements to the technical community. The manufacturing industry/producer should always optimize the PLC and publicize the benefits of using it.

\section{REFERENCES}

Albeck, Jurgen and Sutej, Branimir (1991): "Characteristics of concretes made of Portland limestone cement" beton, vol., 41, no. 5, May1991, pages 240 to 244(In German. English translation by Susan U. Lauer (available from PCA Library)

Hawkins, Peter, Tennis, Paul D. and Detwiller, Rachel J., (2003): The use of limestone in Portland cement: A state-of-theart review, EB227, Portland Cement Association, Skokie. Illinois, USA, 2003, 44 pages. 
Hawkins, Peter, Personal Communication to R. E. Gebhardt, 10 October 1986.

Hooton, R.D., M. Nokken M., and Thomas M.D.A. (2007): Portlandlimestone cement: State-of-the-Art Report and Gap Analysis for CSA A3000. Cement Association of Canada SN 3053

Hooton, Douglas R., (1990): "Effects of Carbonate Additions on Heat of Hydration and Sulfate Resistance of Portland Cement," Carbonate additions to Cement, ASTM STO 1064,P. Klieger and R. D. Hooton, Eds., American Society for Testing and Materials,Philadelphia,1990, pages 73 to 81 .
Nisbet, M.., (1996): Reduction of Resource Input and Emissions Achieved by Addition of Limestone to Portland Cement, PCA R\&D Serial No. 2086, Portland Cement Association, Skokie, Illinois, 1996.

Sprung, S., and Siebel, E., (1991): "Assessment of the Suitability of Limestone for Producing Portland Cement (PKZ)," Zement-Kalk-Gips, vol. 44, no. 1, January 1991, pages 1 to 11 .

Townson, D., (2009): Portland Limestone Cement. Building a sustainable tomorrow, June 16- BCRMCA Board of Directors Meeting and Town Hall Meeting in Nanaimo, $\mathrm{BC}$. 